\title{
MATERIALITY IN FrANCHISE Disclosure: AN ANALYSIS OF HOW "MATERIAL FACTS" HAVE BEEN INTERPRETED UNDER OTHER LEGISLATION
}

\author{
DAVID N. KORNHAUSER
}

\begin{abstract}
As the information imbalance inherent to the franchisor-franchisee relationship can put a franchise purchaser at a significant disadvantage in a transaction, several Canadian provinces have implemented legislation aimed at resolving this disparity. The legislation attempts to strike a balance between empowering potential purchasers in their decisionmaking process and unduly burdening franchisors with an obligation to produce all information available, regardless of utility. Integral to the determination of what must and need not be disclosed to a franchisee prospect is the concept of materiality, specifically the statutory obligation to disclose "material facts" and "material changes." While materiality is inherently contextual and thus cannot be precisely defined, without further guidance from the courts, franchisors will continue to grapple with the extent of disclosure necessary to conduct sound business transactions.
\end{abstract}

\section{TABLE OF CONTENTS}

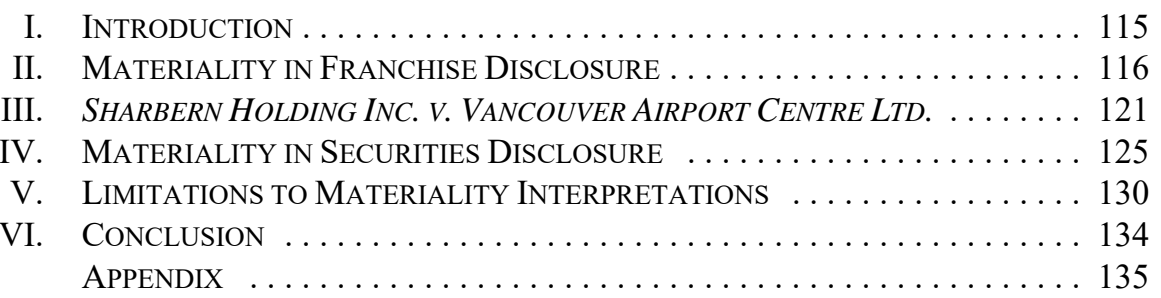

\section{INTRODUCTION}

The soundness of a business decision depends in large part on the quality of the information upon which it is based. This is true whether purchasing a property or investing in a business opportunity. In most cases, the selling party holds the cards; not only is it in possession of a greater wealth of information, it controls the distribution of and access to that information. This information imbalance can put a purchaser or investor at a significant disadvantage in the transaction.

It has long been recognized that such an information imbalance is inherent in the franchisor-franchisee relationship. Several provinces (Ontario, Alberta, Prince Edward Island, New Brunswick, and Manitoba) have enacted legislation aimed at levelling the playing field. Specifically, existing franchise statutes require franchisors to disclose sufficient information to allow a prospective franchisee to make an informed decision about investing in a franchise. While the disclosure requirements are compendious, they are not without limit. The legislation attempts to strike a balance between empowering prospects in their

Corporate Counsel, Macdonald Sager Manis LLP. The author acknowledges Paul B Wronski, a research lawyer associated with Macdonald Sager Manis LLP, for his assistance and insight into the writing of this article. 
decision-making processes and unduly burdening franchisors with an obligation to produce all the information they have at their disposal, regardless of its utility.

Central to the determination of what must and what need not be disclosed is the concept of materiality. All five provinces require the disclosure of material facts as defined. Perhaps surprisingly, the scope of the term "material fact" for the purposes of franchise disclosure has not as yet received significant judicial clarification. Given the potentially draconian consequences of failing to meet statutory disclosure obligations, franchisors are compelled to err on the side of disclosing what is often considered sensitive, proprietary information.

While materiality is inherently contextual and thus incapable of precise definition, absent further elaboration by the courts, franchisors and their counsel will continue to grapple with the extent of franchise disclosure obligations. This article discusses how the concept of materiality has been treated by the courts in other contexts for what guidance, if any, can be had on the question of materiality for the purposes of franchise disclosure.

\section{Materiality In FranChise Disclosure}

Before turning to those other contexts, it is useful to review the role of materiality in existing franchise legislation. While there are differences among the five provincial statutes, each imposes a primary obligation on franchisors to provide prospective franchisees with a disclosure document setting out all material facts. For example, the Ontario legislation, the Arthur Wishart Act (Franchise Disclosure), 2000, requires the delivery of a disclosure document that contains all material facts, including material facts as prescribed, no less than 14 days before the signing of a franchise or related agreement or the payment of any consideration. ${ }^{1}$ The general regulation under the AWA prescribes a menu of particular material facts that must be disclosed. ${ }^{2}$ Those material facts are clearly formulated allowing for the relatively simple preparation of a disclosure document template.

The difficulty in determining what else must be set out in a disclosure document lies in the definition of material fact itself. "Material fact" is defined in section 1(1) of the AWA to include:

[A]ny information about the business, operations, capital or control of the franchisor or franchisor's associate, or about the franchise system, that would reasonably be expected to have a significant effect on the value or price of the franchise to be granted or the decision to acquire the franchise. ${ }^{3}$

Unlike the definition of material fact in the other four provincial franchise statutes, the definition in the AWA is inclusive rather than exhaustive. That is, the Alberta, Prince Edward Island, New Brunswick, and Manitoba statutes define material fact to "mean" rather than 
include the listed types of information. ${ }^{4}$ The $A W A$ definition is open-ended and thus admits greater uncertainty as to what constitutes a material fact.

An additional and, at first blush, apparently significant difference among the provincial statutes is the express inclusion of information "about the franchise" in the Prince Edward Island, New Brunswick, and Manitoba definitions of material fact. ${ }^{5}$ The AWA and Alberta definitions refer only to information about the business, operations, capital or control of the franchisor or its associate, or about the franchise system. When franchisor counsel began preparing disclosure documents to comply with the AWA, that distinction led to the suggestion in Ontario that only the information set forth in the general regulation under the AWA was required to be provided to a prospective franchisee and ergo, site-specific information need not be disclosed in a disclosure document.

That issue appears to have been put to rest. The Ontario Court of Appeal, in 6792341 Canada Inc. v. Dollar It Ltd. ${ }^{6}$ held that the head lease for the franchise's business premises, which had not been included in the franchisor's disclosure document, was material. The sublease, to which the franchisee was a party, contained provisions in which the franchisee acknowledged that it had received a copy of the head lease, was familiar with its terms and agreed to be bound by them. Justice MacFarland concluded that it was absurd, given the acknowledgement, to suggest that the head lease was not material and did not need to be disclosed. ${ }^{7}$

Similarly, in 1159607 Ontario Inc. v. Country Style Food Services Inc., ${ }^{8}$ a case involving a franchise renewal, the Ontario Superior Court of Justice determined that the franchisor's negotiation of an agreement with its landlord that provided for early termination of the head lease for the franchise's business premises was a material fact. The disclosure provided to the franchisee did not contain the sublease but merely stated that one would be coming in due course. No mention was made of the agreement with the landlord. The Court concluded that the franchisor deliberately withheld "critical information that would have an impact on a franchisee's decision to renew." In the Court's view, "[w]ithholding such a material fact from disclosure makes the disclosure completely inadequate and tantamount to no disclosure." 10

In coming to this conclusion, the Court relied on the decision in 1518628 Ontario Inc. $v$. Tutor Time Learning Centres, $L L C,{ }^{11}$ where the franchisor failed to disclose its discovery of serious problems with the franchise's finances and overall management prior to the plaintiff's purchase of the franchise from the previous franchisee. The Court concluded that the franchisor's findings were material facts that were required to be disclosed to a prospective

Franchises Act, RSA 2000, c F-23, s 1(1)(o) [AB Act]; Franchises Act, RSPEI 1988, c F-14.1, s 1(1)(1) [PEI Act]; Franchises Act, SNB 2014, c 111, s 1(1) [NB Act]; The Franchises Act, SM 2010, c 13, CCSM c F156, s 1(1) [Man Act].

Ibid.

2009 ONCA 385, 95 OR (3d) 291 [Dollar It].

Ibid at para 39 .

2012 ONSC 881, 2 BLR (5th) 315, aff'd 2013 ONCA 589, 2013 CarswellOnt 18848 [Country Style]. Ibid at para 108 .

Ibid at para 109.

2006 CanLII 25276 (Ont Sup Ct J) [Tutor Time Learning Centres]. 
franchisee in the position of the plaintiff, ${ }^{12}$ and that, given the circumstances of the case, the franchisor never provided the franchisee with a disclosure document as required by the AWA. ${ }^{13}$

By way of contrast, the Ontario Superior Court held in Caffé Demetre Financing Corp. v. 2249027 Ontario Inc., ${ }^{14}$ another franchise re-sale case, that the substandard state of repair of the franchise's business premises at the time of sale, which the purchaser was ultimately required to remedy, was not a material fact that the franchisor was obligated to disclose. The Court came to this conclusion on two bases. First, there was no evidence that the franchisor should have been aware of the site's condition at the time the disclosure document was delivered. Secondly, the purchaser was clearly aware of the state of the premises before the purchase and had protected itself by inserting into the agreement of purchase and sale a provision requiring the vendor to renovate the store up to the franchisor's standards. ${ }^{15}$ Given this provision, the state of repair issue was cost-neutral to the purchaser and thus could not have had a significant effect on the price paid for the franchise.

The purchaser in Caffé Demetre asserted three other failures to disclose material facts regarding system issues. Two related to policies implemented 14 and 20 months after the disclosure document was delivered. ${ }^{16}$ The Court was of the view that the policies could not be considered material facts that should have been disclosed as neither existed at the time the disclosure document was delivered. The third alleged material fact was the litigation commenced by the franchisor against a former franchisee to enjoin the latter from using the franchisor's recipes and other confidential information in a competing enterprise. Accepting that the litigation was contemplated at the time the disclosure document was delivered, the Court concluded, apparently on the basis of existing precedent, that it was a material fact that should have been disclosed..$^{17}$ However, this single deficiency did not amount in law to no disclosure at all and thus did not entitle the purchaser to rescind almost two years after the franchise agreement was executed as was claimed. ${ }^{18}$

The purchaser's appeal was dismissed. ${ }^{19}$ The Court of Appeal disagreed with the motion judge's characterization of the litigation against the former franchisee as a material fact. Although section 2(5) of the general regulation under the $A W A^{20}$ mandates the disclosure of certain kinds of litigation, the action at issue did not fall within the ambit of that provision. However, the material fact inquiry does not end there. Even if past or pending litigation involving the franchisor, its associates, directors, general partners, or officers does not fall within the regulation, the fact-specific analysis of whether the litigation is a material fact must still be performed. ${ }^{21}$ In this case, the motion judge recognized that the litigation was a protective measure taken by the franchisor, at the request of and for the benefit of the franchisees, and that "[i]t did not constitute a potential liability that might attach to the

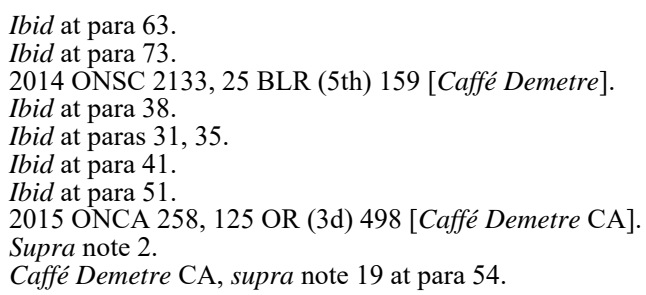


franchise system as a whole." ${ }^{22}$ The Court of Appeal concluded that, having so found, the motion judge erred in finding the litigation to be a material fact. The failure to disclose did not "deprive the [purchaser] of the opportunity to make a properly informed decision to invest in the ... franchise." 23

The omitted information found to be material in the cases discussed above, other than the three additional disclosure failures asserted in Caffé Demetre, does not appear to be directly related to the business, operations, capital or control of the franchisor or its associates, or to the franchise system. Those decisions could be explained by the inclusive nature of the definition of material fact in the AWA rather than through the implication of the words "about the franchise." Nonetheless, they are consistent with, and perhaps predicated on, the intention of the legislature in creating the AWA. Ontario courts have consistently interpreted the AWA as legislation specifically intended to protect the interests of franchisees. ${ }^{24}$ Indeed, the Ontario Court of Appeal has termed the AWA "sui generis remedial legislation" deserving of a broad and generous interpretation to redress the imbalance of power between franchisor and franchisee. ${ }^{25}$ In any event, it is apparent that franchisors in Ontario must assess sitespecific information to determine whether it could have a significant effect on the price of the franchise or the decision to acquire it.

Materiality also plays a role with respect to a franchisor's obligation to update or supplement its disclosure document. This duty arises where there is a "material change" as defined in the legislation. All five provincial statutes require a franchisor to provide prospective franchisees with a written statement of any material change as soon as practicable but, in any event, prior to the signing of any agreement relating to the franchise or the payment of any consideration. The definition of material change in each statute is similar to the definition of material fact with one important distinction: the change must still be in relation to "the business, operations, capital or control of the franchisor or franchisor's associate," or the franchise system. ${ }^{26}$ This includes a decision to implement such a change where the decision is made by the franchisor's board of directors or by senior management of the franchisor or franchisor's associate, and those persons believe implementation by the board is probable. However, in order to meet the definition of material change, the change must reasonably be expected to have a significant adverse effect on the value or price of the franchise or the decision to acquire it.

In addition to the obligation to provide a written statement of material change to prospective franchisees, material change can trigger an obligation to deliver a disclosure document to existing franchisees in certain circumstances. All of the provinces exempt franchisors from providing a disclosure document on the sale of an additional franchise to an existing franchisee if the additional franchise is substantially the same as the existing franchise. If, on the other hand, there has been a material change since the execution (or

Caffé Demetre, supra note 14 at para 42.

Caffé Demetre CA, supra note 19 at para 63 [citations omitted].

Dollar It, supra note 6 at para 72; Country Style, supra note 8 at para 71.

Salah v Timothy's Coffees of the World Inc, 2010 ONCA 673, 74 BLR (4th) 161 at para 26.

AWA, supra note $1, \mathrm{~s} 1(1)$; see also the other provincial statutes, supra note 4 . The AWA definition includes a "prescribed change." To date, no regulations have been made prescribing "material changes."

As is the case with respect to the definition of material fact, the Manitoba, New Brunswick, and Prince Edward Island definitions of "material change" include changes to the franchise. 
renewal or extension) of the original franchise agreement, the AWA and the Manitoba, New Brunswick, and Prince Edward Island statutes require the delivery of a disclosure document on the sale of the additional franchise. ${ }^{27}$

Similarly, the existing legislation exempts franchisors from providing a disclosure document on the renewal or extension of a franchise agreement. However, the exemption applies in Ontario, Manitoba, New Brunswick, and Prince Edward Island only when there has been no interruption in the operation of the franchise and no material change since the franchise agreement was entered into. This issue was addressed by the Ontario Superior Court of Justice in MDG Kingston Inc. v. MDG Computers Canada Inc. ${ }^{28}$ in which it was held that a number of changes to the renewal agreement affecting the costs of services, the purchase price of goods, the allocation of expenses among franchisees and the punitive penalty and warranty service provisions were material, as they would reasonably have been expected to have an effect on the decision of the franchise to continue to operate. ${ }^{29}$ Thus, the franchisor could not avail itself of the exemption from the obligation to provide a disclosure document on renewal. While the Court could have been more precise in its language, it appears implicit in its reasoning that the changes in the renewal agreement "would have reasonably been expected to have an effect on the decision of the franchisee to acquire the franchise, or to continue in operation." ${ }^{30}$

Materiality also plays a crucial role with respect to the statutory right of a franchisee to sue for misrepresentations contained in disclosure documents or statements of material change. ${ }^{31}$ Misrepresentation for the purposes of each Act includes an untrue statement of material fact or an omission to state a material fact that is required to be stated or that is necessary to make a statement not misleading. In Ontario, Manitoba, New Brunswick, and Prince Edward Island, the question as to whether a material fact is necessary to make a statement not misleading is to be determined in light of the circumstances in which the statement is made. ${ }^{32}$

What is clear from the foregoing is that a fact or a change will be material if it would reasonably be expected to have, in the case of the former, a significant effect, or, in the case of the latter, a significant adverse effect, on the value or price of the franchise or on the decision to acquire it. Thus, materiality is to be assessed on an objective standard. That is, the person asserting materiality must show that the effect or adverse effect would reasonably be expected. Beyond that, the legislation is silent. The decisions referred to above similarly shed scant light on how the materiality is to be assessed in a particular factual matrix. Rather, they are, in the main, declaratory. The Court, in the first three instances, simply identified the undisclosed fact, appeared to have assumed the obviousness of its materiality to the value

AWA, supra note 1, s 5; Man Act, supra note 4, s 5; NB Act, supra note 4, s 5; PEI Act, supra note 4, s 5 .

[2007] OJ No 5561 (QL) (Ont Sup Ct J), rev'd on other grounds 2008 ONCA 656, 299 DLR (4th) 497. Ibid at para 4.

Ibid.

The Alberta statutory cause of action is limited to misrepresentations contained in a disclosure document. See $A B$ Act, supra note 4 , s 9 .

See the definition of "misrepresentation" in AWA, supra note 1, s 1(1); Man Act, supra note 4, s 1(1); NB Act, supra note 4, s 1(1); PEI Act, supra note 4, s 1(1)(n). 
or price of the franchise, or the decision to acquire it, declared it to be so, and granted a remedy.

It is worth noting, however, that franchise legislation has a relatively short history in Canada. The oldest of the existing statutes, the Alberta Act, came into force in 1995, and the $A W A$ in $2000 .{ }^{33}$ Franchisors have since been working to transition into the new statutory disclosure regime, with varying degrees of compliance. Many of the cases interpreting the statutory disclosure obligations have dealt with more obvious omissions, such as failures to include items specifically prescribed by regulation. Ontario cases have tended to focus not so much on the materiality of omissions but on their consequences and, in particular, on whether a franchisor's individual or cumulative failures to meet the legislated disclosure requirements entitle a franchisee to rescind its franchise agreement within 60 days of receiving a disclosure document or within the longer two-year period following the execution of the agreement.

A more refined jurisprudence will no doubt evolve as franchisors and their counsel develop a more sophisticated appreciation of their statutory obligations. As the courts and practitioners work through the process of interpreting those obligations, judicial focus will likely shift to more nuanced assertions of non-compliance based on the alleged materiality of omitted information. Recent judicial pronouncements on materiality in the context of other statutory disclosure regimes could inform how the courts ultimately assess materiality for the purposes of determining compliance with franchise disclosure obligations.

\section{SHARBERN HOLDING INC. V. VANCOUVER AIRPORT CENTRE LTD.}

In Sharbern Holding Inc. v. Vancouver Airport Centre Ltd., ${ }^{34}$ the Supreme Court of Canada addressed the question of liability for alleged material false statements contained in statutorily mandated disclosure materials. Sharbern was a class action commenced on behalf of investors in one of two hotels, the Hilton and the Marriott, being developed by Vancouver Airport Centre Ltd. (VAC). The Hilton investors alleged that VAC failed to disclose differences in the financial arrangements, referred to as "Compensation Differences," regarding the two hotels that incentivized VAC to favour the Marriott development. This, it was alleged, created a conflict of interest that was not disclosed to the Hilton investors. Rather, the Hilton Disclosure Statement, which, due to the nature of the investment vehicles involved was governed by both the British Columbia Securities Act ${ }^{35}$ and the British Columbia Real Estate Act, ${ }^{36}$ contained a statement to the effect that the developer had entered into agreements with the Marriott investors that were "similar in form and substance" to those entered into with the Hilton investors. ${ }^{37}$ The Disclosure Statement also stated that the developer was "not aware of any existing or potential conflicts of interest ... that could reasonably be expected to materially affect the purchaser's investment decision." ${ }^{38}$

The AWA came into force in two stages. The provisions dealing with matters other than disclosure came into force in 2000. The disclosure provisions came into force in 2001.

2011 SCC 23, [2011] 2 SCR 175 [Sharbern].

RSBC 1996, c 418.

RSBC 1996, c 397, as repealed by Real Estate Services Act, SBC 2004, c 42.

Sharbern, supra note 34 at para 39.

Ibid at para 95 [citation omitted]. 
The Hilton investors alleged that both of these statements were misrepresentations, which resulted in the "non-disclosure of a material conflict of interest." ${ }^{39}$ In particular, they claimed that VAC was in breach of section 75(2)(b) of the Real Estate Act, which imposed liability on developers for "material false statements" contained in their disclosure documents. ${ }^{40}$ The trial judge agreed. The Supreme Court did not, focusing its analysis on "what is meant by the term 'material' when it is used in the context of the 'material false statement' required for liability under s. 75 " of the Real Estate Act. ${ }^{41}$

The Real Estate Act did not define the term "material false statement," nor did it provide legislative guidance for the interpretation of materiality. Although the analysis of materiality is in relation to the Real Estate Act, the Court adopted the reasoning of the US Supreme Court in TSC Industries, Inc. v. Northway, Inc., ${ }^{42}$ a securities case that considered the materiality of a fact omitted from a proxy solicitation. The test for materiality was described as follows:

\begin{abstract}
An omitted fact is material if there is a substantial likelihood that a reasonable shareholder would consider it important in deciding how to vote. This standard is fully consistent with Mills' general description of materiality as a requirement that "the defect have a significant propensity to affect the voting process." It does not require proof of a substantial likelihood that disclosure of the omitted fact would have caused the reasonable investor to change his vote. What the standard does contemplate is a showing of a substantial likelihood that, under all the circumstances, the omitted fact would have assumed actual significance in the deliberations of the reasonable shareholder. Put another way, there must be a substantial likelihood that the disclosure of the omitted fact would have been viewed by the reasonable investor as having significantly altered the "total mix" of information made available. ${ }^{43}$
\end{abstract}

The Supreme Court in Sharbern accepted as analogous a disclosure statement under the Real Estate Act and a proxy solicitation as discussed in TSC Industries because "both are (i) prepared unilaterally by management or a developer, (ii) prepared pursuant to statutory and/or regulatory obligations, (iii) used to provide information to investors (current or potential) to allow them to make informed choices, and (iv) used by investors in making decisions (either deciding how to vote or whether to invest).",44

After reviewing the reasons of the US Supreme Court in TSC Industries, Justice Rothstein summarized the important aspects of the common law test for materiality as follows:

Ibid at para 37 [citation omitted]. As stated, the disclosure in Sharbern was governed by that Act and the Securities Act (supra note 35). The BC Superintendent of Real Estate and the BC Securities Commission allowed developers to issue one document that combined what would otherwise be an offering memorandum under the Securities Act and a prospectus or disclosure statement under the Real Estate Act. The Superintendent of Real Estate had the discretion to allow a developer to issue a disclosure statement, rather than a prospectus, that limited its disclosure obligations to certain prescribed matters. That discretion was exercised in this case. However, section 66(2) of the Real Estate Act deemed the hybrid Disclosure Statement issued to the Hilton investors to be a prospectus for the purposes of section 75 of that Act.

Sharbern, supra note 34 at para 44.

426 US 438 (1976) [TSC Industries].

Ibid at 449, citing Mills $v$ Electric Auto-Lite Co, 396 US 375 at 38 [footnote omitted] [emphasis in original].

Sharbern, supra note 34 at para 47. 
i. Materiality is a question of mixed law and fact, determined objectively, from the perspective of a reasonable investor;

ii. An omitted fact is material if there is a substantial likelihood that it would have been considered important by a reasonable investor in making his or her decision, rather than if the fact merely might have been considered important. In other words, an omitted fact is material if there is a substantial likelihood that its disclosure would have been viewed by the reasonable investor as having significantly altered the total mix of information made available;

iii. The proof required is not that the material fact would have changed the decision, but that there was a substantial likelihood it would have assumed actual significance in a reasonable investor's deliberations;

iv. Materiality involves the application of a legal standard to particular facts. It is a fact-specific inquiry, to be determined on a case-by-case basis in light of all of the relevant considerations and from the surrounding circumstances forming the total mix of information made available to investors; and

v. The materiality of a fact, statement or omission must be proven through evidence by the party alleging materiality, except in those cases where common sense inferences are sufficient. A court must first look at the disclosed information and the omitted information. A court may also consider contextual evidence which helps to explain, interpret, or place the omitted information in a broader factual setting, provided it is viewed in the context of the disclosed information. As well, evidence of concurrent or subsequent conduct or events that would shed light on potential or actual behaviour of persons in the same or similar situations is relevant to the materiality assessment. However, the predominant focus must be on a contextual consideration of what information was disclosed, and what facts or information were omitted from the disclosure documents provided by the issuer. ${ }^{45}$

While the Court recognized that common sense inferences regarding materiality can be drawn in certain circumstances, it noted that "where there is evidence that supports competing inferences, a court may be required to carry out a more complex analysis to determine what the reasonable investor would have considered important." ${ }^{26}$ Justice Rothstein was of the view that the trial judge erred by appearing to draw a common sense inference about the materiality of the Compensation Differences. That is, "she equated the existence of a potential or actual conflict of interest with materiality, essentially treating a conflict of interest as inherently material." ${ }^{, 77}$ But, as Justice Rothstein stated, the issue was not whether an actual or potential conflict of interest existed but "whether the Compensation Differences and the potential or actual conflict of interest they created were material, thereby rendering VAC's failure to disclose them 'material false statements' attracting liability under the statute." 48 The trial judge appeared "to make a common sense inference that the Compensation Differences would have been material, without offering any analysis of how the conflict created by the Compensation Differences would fit into the mix of all other relevant information, nor [did] she take notice of what the total mix of information would be. ${ }^{49}$ The Court added:

\footnotetext{
$45 \quad$ Ibid at para 61 [emphasis in original].

$46 \quad$ Ibid at para 52.

$47 \quad$ Ibid at para 62.

$48 \quad$ Ibid at para 63 [emphasis in original].

$49 \quad$ Ibid at para 67
} 
There was evidence ... which could have supported the opposite inference, that the Compensation Differences or the omitted information were not material in the context of what had already been disclosed to investors. For example, the disclosed information included information about the economic environment at the time of the sale of the strata lots; the financial benefits offered to the Hilton Owners, such as the management fee payable to VAC; information about common management by VAC and resulting risk factors; and information relevant to VAC's limited ability to prefer its own interests. The trial judge also had behaviour evidence led by VAC about what the conduct of fully informed investors had been. In my view, this evidence demonstrated that competing inferences could be drawn in this case and added a layer of complexity to the materiality analysis that took it outside the realm of drawing a simple, common sense inference. A more detailed analysis of the evidence constituting the "total mix" of information was required in order to make a determination about what a reasonable investor would have considered significant. ${ }^{50}$

While those other factors might have been of little weight in determining whether a potential or actual conflict of interest existed, in Justice Rothstein's opinion, they "constituted disclosed information that would come into play as relevant to the issue of whether reasonable investors would have considered the omitted information important to their investment decision." 51 Ultimately, the Court concluded that it had "not been demonstrated that there was substantial likelihood that disclosure of the Compensation Differences would have assumed actual significance in a reasonable investor's investment decision." 52

It is important to note that the statutory disclosure requirements in Sharbern only obliged issuers to disclose certain prescribed information. There was no open-ended obligation to disclose all material facts; nonetheless, Sharbern has been applied in the franchise context. ${ }^{53}$ However, none of the decisions reported to date involve the kind of fine analysis of materiality that was performed by Justice Rothstein. With respect to the first three franchise cases discussed above, it seems clear that common sense inferences were available regarding the materiality of a head lease that had not been provided but to which the franchisee agreed to be bound, ${ }^{54}$ or the negotiation by a franchisor and its landlord of an early termination provision in a head lease for a franchisee's business premises. ${ }^{55}$ The same could perhaps be said about a franchisor's actual knowledge of specific financial or management problems experienced by a franchisee that intends to sell or assign its franchise where no disclosure exemption is available to the franchisor. ${ }^{56}$

While these decisions provide franchisors and their advisors with some direction regarding what must be disclosed beyond prescribed facts, they do not offer much definition about the limits of the disclosure obligations. Put another way, franchisors are still left wondering, at least to a certain extent, what they need to disclose in order to preclude the possibility of their

Ibid at para 68 .

Ibid at para 73 .

Ibid at para 91 .

See e.g. Mapleleaf Franchise Concepts Inc v Nassus Frameworks Ltd, 2011 ABQB 594, [2011] AJ No

1034 (QL); Trillium Motor World Ltd v General Motors of Canada Ltd, 2012 ONSC 463, [2012] OJ No

1578 (QL) (Div Ct).

Dollar It, supra note 6 .

Country Style, supra note 8.

Tutor Time Learning Centres, supra note 11. 
franchisees from relying upon the rescission provisions of existing franchise legislation to undo what in most cases would otherwise be valid and enforceable franchise agreements.

\section{MATERIALITY IN SECURITIES Disclosure}

The Ontario Securities Commission (OSC) has stated that "disclosure is the cornerstone principle of securities regulation." 57 The mandate of the OSC is to pursue and fulfill the purposes of the Ontario Securities Act, the stated purposes of which are "(a) to provide protection to investors from unfair, improper or fraudulent practices; and (b) to foster fair and efficient capital markets and confidence in capital markets. ${ }^{, 58}$ One of the primary means of achieving the purposes of the $S A$ is the "requirement for timely, accurate and efficient disclosure." 59 Generally speaking, the $S A$ prohibits any person or company from trading in securities (where the trades would be distributions as that term is defined) "unless a preliminary prospectus and a prospectus have been filed and receipts have been issued for them." ${ }^{, 60}$ Prospectuses under the SA must "provide full, true and plain disclosure of all material facts relating to the securities issued" and must comply with Ontario securities law. ${ }^{61}$ Where a "material adverse change occurs" after a prospectus is filed and a receipt is obtained but before distribution, amendments to the prospectus must be filed no later than ten days after the change occurs. ${ }^{62}$ In addition to these basic requirements, the $S A$ imposes continuous disclosure obligations on reporting issuers. Specifically, section 75 of the $S A$ requires reporting issuers to issue and file a news release and file a material change report "where a material change occurs in the affairs of a reporting issuer," forthwith in the case of the former and within 10 days of the date on which the change occurs in the case of the latter. ${ }^{63}$

No such continuous disclosure obligation exists under current franchise legislation. While the two disclosure regimes differ in this and several other respects, the $S A$, like the $A W A$ and its brethren, requires the disclosure of material facts and material changes. "Material fact" is defined in section 1(1) of the $S A$, when used in relation to securities issued or proposed to be issued, to mean "a fact that would reasonably be expected to have a significant effect on the market price or value of the securities." ${ }^{64}$ The definition is much broader than the corresponding definition in the AWA, not being limited to facts about the business, operations, capital or control of the disclosing entity. Even so, the SA definition does not require consideration of the effect of a fact on the decision to acquire the securities.

The definition of material change in the AWA is similar however, to the definition of that term in the $S A$. For the purposes of this discussion, "material change" is defined in section 1(1) of the latter to mean:

i) a change in the business, operations or capital of the issuer that would reasonably be expected to have a significant effect on the market price or value of any of the securities of the issuer, or

Re Philip Services Corp (2006), 29 OSCB 3971 at para 7.

RSO 1990, c S.5, s 1.1 [SA].

Ibid, s 2.1 (2)(i).

Ibid, s 53(1).

Ibid, s 56(1).

Ibid, s 57(1).

Ibid, ss 75(1)-(2).

Ibid, s 1(1). 
ii) a decision to implement a change referred to in subclause (i) made by the board of directors or other persons acting in a similar capacity or by senior management of the issuer who believe that confirmation of the decision by the board of directors or such other persons acting in a similar capacity is probable. ${ }^{65}$

Although the $S A$ definition clearly differs from those contained in the franchise statutes (in that the obligation to disclose material changes does not extend beyond the issuer to its associates, does not include changes in control of the issuer or refer to the decision to acquire securities), the definitions are sufficiently similar for comparative purposes.

A considerable body of case law has been developed by Canadian securities regulators and the courts regarding an issuer's disclosure obligations that could provide some guidance to franchisors. In 2013, the Ontario Divisional Court considered a reporting issuer's continuous disclosure obligations in Cornish v. Ontario Securities Commission, ${ }^{66}$ a case related to the collapse of the asset-backed commercial paper (ABCP) market in 2007. The decision is instructive on how an external event can be material such that it triggers an obligation to disclose.

The facts warrant some consideration. Coventree Inc. (Coventree) became a reporting issuer following an initial public offering on 15 November 2006. It derived the bulk of its revenues from securitization transactions and, in particular, credit arbitrage transactions in the ABCP market. ${ }^{67}$ As the OSC observed, that market was opaque. There was no public reporting of prices at which $\mathrm{ABCP}$ transactions were effected, no securities law filing obligations regarding the sale or trade of $\mathrm{ABCP}$, and no duty to disclose information about the attributes of, or assets backing, ABCP ${ }^{68}$ Investors thus had little ability to conduct their own due diligence and essentially relied on the credit rating of these instruments to make their investment decisions.

Shortly before Coventree filed its final prospectus, the credit rating agency, Dominion Bond Rating Service (DBRS), sent a letter to various market participants dated 10 November 2006 advising them that it would be taking a measured approach to future growth of certain types of transactions in the ABCP market and that approval would be more restrictive going forward. ${ }^{69}$ DBRS subsequently issued a press release in January 2007 "announcing changes to its credit rating criteria for certain credit arbitrage transactions" that effectively required Coventree to secure unattainable liquidity to back those types of transactions. ${ }^{70}$ Coventree mentioned the January 2007 DBRS press release in a letter to its shareholders sent in February 2007 and stated in its Management's Discussion \& Analysis (publically filed in May 2007) that the DBRS press release would "have the effect of reducing the profitability of the Company by substantially curtailing its ability to grow, if not halt in the short term, its credit arbitrage business." ${ }^{, 71}$ The value of Coventree's shares did not change significantly after these disclosures.

Ibid.

2013 ONSC 1310, 306 OAC 107 [Cornish].

Ibid at para 8 .

Ibid at para 9 .

Ibid at para 67.

Ibid at para 11 [citations omitted].

Ibid at para 12 . 
By July 2007, the ABCP market was in serious decline and in late July and early August, Coventree took a number of steps to attempt to address liquidity issues and events related to the lack of demand for new ABCP. ${ }^{72}$ The Board of Directors met on 1 August 2007 to discuss market conditions and to consider whether a material change had occurred. A press release was drafted but never released. On 13 August 2007, the market for Coventreesponsored ABCP collapsed leaving investors holding the bag. The following day, Coventree issued a press release disclosing the market disruption as a material change. ${ }^{73}$

OSC Commission Staff levelled a number of allegations against Coventree and two of its principals, Cornish and Tai. They alleged that Coventree failed to provide full, true, and plain disclosure of all material facts in its final prospectus by failing to mention the 10 November 2006 DBRS letter. Although the OSC in its decision found that the letter contained information that was important to Coventree and its business, and was "surprised" that it was not mentioned in the prospectus, it held that the letter was not a "material fact" at the date of the prospectus. ${ }^{74}$ It did so for three reasons. First, it was unclear "what DBRS was saying in the [letter] and what criteria it would apply in reviewing future ... transactions." ${ }^{, 75}$ Second, the letter appeared to be a continuation of its measured approach to approving transactions. Finally, the letter did not affect outstanding transactions or those currently being reviewed by DBRS. ${ }^{76}$

The OSC did conclude, however, that Coventree had breached its continuous disclosure obligations by failing to issue and file a press release and by failing to file a material change report contrary to section 75 of the SA in relation to the January 2007 DBRS press release that announced the change to DBRS's credit rating criteria. ${ }^{77}$ The OSC held that Coventree had similarly breached those obligations with respect to liquidity-related events leading up to the market disruption that occurred on 13 August 2007. ${ }^{78}$ In the OSC's opinion, the January press release and the liquidity events were material changes that Coventree was required to disclose. Cornish and Tai, as directors and officers of Coventree, were found to have authorized, permitted or acquiesced in those breaches and were thus deemed in breach of section 129.2 of the $S A .^{79}$

Cornish and Tai appealed the finding that Coventree had breached its continuous disclosure obligations. In affirming the decision below, the Divisional Court reviewed the reasonableness of the OSC's materiality analysis regarding the changes that the Commission determined should have been disclosed. ${ }^{80}$ As to general principles, Justice Ducharme stated that "[o]ne of the central policies underlying the Securities Act ... is the "protection of the investing public through full, true and plain disclosure of all material facts relating to securities being issued." "81 Referring to TSC Industries, the Court noted that "while

Ibid at para 13 .

Ibid at paras 13-15.

Coventree Inc, Re (2011), 34 OSCB 10209, 91 BLR (4th) 108 at paras 202, 205.

Ibid at para 207.

Ibid at paras 210-11.

Ibid at para 342 .

Ibid at paras 593-55.

Ibid at para 771 .

Cornish, supra note 66

Ibid at para 38, citing Pacific Coast Coin Exchange of Canada Ltd v Ontario (Securities Commission), [1978] 2 SCR 112 at 126. 
disclosure is important, '[t] oo much disclosure or information overload can be counterproductive' in terms of enabling investors to make informed choices." ${ }^{\prime 2}$

Justice Ducharme discussed the principles that guide materiality assessments in this context. The question of whether section 75 of the $S A$ is engaged involves a two-step analysis. First, a "determination [must be made] as to whether a change in the 'business, operations or capital' of the issuer has occurred and, if so, when." ${ }^{, 3}$ The second step "requires an assessment of whether the change was material in the sense that it "would reasonably be expected to have a significant effect on market price or value of the securities." $" 84$ Further, "materiality should be assessed objectively from the perspective of an investor and prospectively through the lens of expected market impact." ${ }^{85}$ An overly technical interpretation of statutory language should not be relied upon to justify nondisclosure. If a "decision is borderline, then the information should be considered material and disclosed." " However, materiality assessments "are not to be made against a standard of perfection or with the benefit of hindsight." ${ }^{87}$ The Court went on to add that materiality is highly contextual and that "common sense must prevail in assessing the broader factual context." ${ }^{, 88}$ Importantly, disclosure obligations are not subject to the business judgment rule. That is, "disclosure requirements ... are not to be subordinated to the exercise of business judgment, ${ }^{, 89}$ a point that was also made by the Supreme Court in Sharbern. ${ }^{90}$

One of the appellants' principal arguments was that the OSC erred with respect to the test it applied to determine whether a material change had occurred. Specifically, the appellants submitted that the Commission applied the reasonable investor test - the test articulated by the US Supreme Court in TSC Industries and applied in Sharbern — in that "the Commission's fundamental consideration was whether there was something not disclosed that 'would be important to a reasonable investor in making an investment decision.",91 Rather, the appellants argued that the Commission should have applied the market impact test focusing on whether a change had occurred in the business, operations, or capital of Coventree that was material in that it would reasonably be expected to have a significant effect on the market price or value of its shares. Justice Ducharme agreed "that the reasonable investor test sets a lower threshold for materiality than does the market impact test," 92 but ultimately rejected this argument, finding that the market impact test was applied by the Commission with respect to the particulars alleged against Coventree and the appellants, despite repeated references to what would be important to a reasonable investor. ${ }^{93}$ While the Commission was of the view that it was only common sense that the January 2007 DBRS press release announcing changes to its credit rating criteria which negatively affected a substantial portion of Coventree's business was something that a reasonable investor would

Cornish, ibid at para 41, citing Re YBM Magnex International Inc (2003), 26 OSCB 5285 at para 89 [YBM Magnex].

Cornish, ibid at para 46, citing SA, supra note 58, s 75 .

Ibid.

Cornish, ibid at para 47.

YBM Magnex, supra note 82 at para 518, cited in Cornish, ibid at para 48.

Cornish, ibid at para 49 [footnote omitted].

Ibid at para 52 [footnote omitted].

Ibid at para 55, citing Kerr v Danier Leather Inc, 2007 SCC 44, [2007] 3 SCR 331 at paras 54-55.

Sharbern, supra note 34 at paras 55-57.

Cornish, supra note 66 at para 60 .

Ibid at para 73.

Ibid at para 66 . 
want to know, it also concluded that the press release constituted a change in Coventree's business that would reasonably be expected to have a significant effect on the market price or value of Coventree shares. ${ }^{94}$ Simply sending a letter to shareholders and mentioning the press release in its Management's Discussion \& Analysis filing did not meet the requirements of section 75 of the $S A$. A similar conclusion was reached with respect to the liquidity-related events that occurred in August 2007.95

The appellants also submitted that the Commission reached its conclusions in the absence of evidence capable of supporting a finding that a material change had occurred. They rejected the suggestion that common sense inferences could be drawn to the effect that the DBRS press release and the August events would reasonably be expected to have a significant impact on the market price or value of Coventree shares. Justice Ducharme disagreed, finding that there was extensive evidence capable of supporting the Commission's conclusions. ${ }^{96}$ Furthermore, "[n]ot only was the conclusion that material changes had occurred an available common sense inference; it was the only reasonable inference available to the Commission on the evidence before it." 97

The Coventree case illustrates the importance of timing in disclosure. The OSC found that the November 2006 DBRS letter was not a material fact that was required to be disclosed in the prospectus essentially because its impact was unclear. However, both it and the Divisional Court concluded that the January 2007 press release, which came out after Coventree went public, was a material change. It seems evident that, had the press release been issued prior to the completion of Coventree's distribution, it would have constituted a material fact that would have had to have been disclosed in the prospectus. In the franchise context, had the 2006 letter, or something akin to it, come out before the franchise or related agreement had been signed or any consideration paid, it would not, on the analysis in Coventree, have to be disclosed. If the 2007 press release had been issued after either of those events, it would not have to be disclosed because franchisors are under no continuous disclosure obligation. Such a fact would only have to be disclosed under the rubric of "material change" if expressly required to do so by statute, such as, perhaps, on the sale of an additional franchise or upon renewal.

The OSC has adopted a number of non-binding policies that provide market participants with the Commission's interpretation of securities law. Part IV of National Policy 51-201 on Disclosure Standards ${ }^{98}$ deals with materiality and offers examples of changes to corporate and capital structure and in business and operations, among other things, that, in the Commission's view, could be material. Although investing in a securities distribution is not the same thing as purchasing a franchise, the disclosure regimes share a common purpose, namely, the protection of investors and purchasers. As such, the examples suggested by the OSC may provide franchisors and practitioners with some guidance as to what types of facts or changes could be material for the purposes of franchise disclosure. 


\section{LIMITATIONS TO MATERIALITY INTERPRETATIONS}

As Sharbern and Cornish demonstrate, common sense inferences regarding materiality will suffice in many disclosure determinations. However, that will not always be the case a point made by the British Columbia Court of Appeal in Woo v. ONNI Ioco Road Five Development Limited Partnership, ${ }^{99}$ a decision that considered disclosure under the British Columbia Real Estate Development Marketing Act. ${ }^{100}$ REDMA mandates the disclosure of material facts in relation to the sale of development units, including strata lots. "Material fact" is defined to mean, among other things, "a fact, or a proposal to do something, that affects, or could reasonably be expected to affect, the value, price or use of [a] development unit." ${ }^{101}$ Developers are required to provide purchasers with a disclosure statement before entering into a purchase agreement for the sale of such a unit. ${ }^{102}$ Disclosure statements must "without misrepresentation, plainly disclose all material facts." 103 Where a "developer becomes aware that a disclosure statement does not comply with the Act or regulations, or contains a misrepresentation," it must provide to purchasers a new disclosure statement or an amendment to the original that corrects the failure to comply or the misrepresentation. ${ }^{104}$

The purchasers in Woo received the original disclosure statement. An amendment was prepared and filed with the Superintendent of Real Estate stating that subdivision and municipal development approvals had been obtained, a building permit had been secured, construction had commenced, and confirmed the estimated date of substantial completion. ${ }^{105}$ The original disclosure statement had stated that the developer was seeking the approvals and intended to secure a building permit.

The purchasers did not receive the amendment through inadvertence. They asserted that the facts contained in the amendment were material. Having not received disclosure of them, the purchasers argued that they were entitled to rescind their agreements. The Court of Appeal disagreed. Justice Harris was of the view that "[o]n a common sense basis, the 'facts' stated nothing more than the fulfilment of events exactly as predicted in the disclosure statement and such disclosure would not reasonably affect value, use or price." ${ }^{\prime 106}$ The Court was similarly of the view that the facts were not material, stating:

First, in the absence of evidence, I do not think it follows that a reasonable person could conclude that the disclosure in the amendment was material. In my view, the effect, if any, of making the disclosure that, for example, the building permit had been issued as predicted and that construction had started and was proceeding on schedule is speculative. Whether that disclosure would have any effect in changing a reasonable person's assessment would depend on the facts. Was there any reason to think that the building permit might not be issued as predicted? Was there any basis to be concerned about a risk to the construction schedule? If so, had the market already factored these risks into value or price?

2014 BCCA 76, 60 BCLR (5th) 56 [Woo].

SBC 2004, c 41 [REDMA].

Ibid, $\mathrm{s} 1$.

Ibid, s $15(1)$ (a).

Ibid, s 14(2)(b).

Ibid, s 16(1)(b).

Woo, supra note 99 at para 15.

Ibid at para 22 . 
Certainly, the risk of the developer failing to complete is "reduced" by comparison with a counterfactual world in which events did not unfold as predicted. Hence, if the issuance of the building permit was delayed, postponing construction, there would have been a change that might well have been material and of which [purchasers] were entitled to be informed. But those are not the facts. There was no evidence that there were reasons to think that there was a material risk that this project would not complete as predicted and that achieving a building permit removed a risk that had, for example, led to the price of the units being materially discounted when they first went on sale. There was no evidence, for example, that the price of the units would step up as each event (subdivision, building permit, construction start) occurred.

Secondly, even if there might be some effect on price, value or use resulting from passing milestones as predicted, there was no evidence about how significant an effect there was. I do not think it possible to draw a common sense conclusion about the magnitude of any potential effects the disclosure of the facts in issue here would have on price, value or use. In my view, the notion of "materiality" imports some threshold component of the objective significance or the objective degree of the effect on their interests before a purchaser is entitled to disclosure. A purchaser is entitled to information of a suffciently substantial nature that objectively affects their interests so that they can assess their rights under REDMA and avail themselves of their remedies. In my opinion, some minimum threshold consequence on price, value or use is built into the purpose of consumer protection. It is not necessary here to attempt to define what that threshold is or the magnitude of an effect before information is material. My point is that, in these circumstances, there was no adequate foundation for the judge's conclusion that this information was material. ${ }^{107}$

The Court was also of the opinion "that a proper interpretation of the definition of 'material fact' engages the notion that the effect on value, price and use must be adverse to the interests of the purchasers and not to their benefit." ${ }^{108}$ While this might be the proper interpretation of "material fact" under REDMA, the definition of that term in existing franchise legislation does not require an adverse effect and no such qualification would likely be implied given the express inclusion of that word in the definition of material change. The Court went on to add:

I accept that REDMA imposes strict disclosure obligations as part of its consumer protection purpose and that statutory language creating those obligations should be read generously in favour of consumers. Where there has been non-disclosure of adverse material facts, s. 21(3) gives a broad right to rescind at any time. The nature of this right underscores the importance placed by the Legislature on timely disclosure. It creates a powerful incentive for developers to correct misrepresentations by disclosing material facts to preserve binding purchase agreements. Nonetheless, there is a difference between consumer protection and a windfall that allows purchasers to rescind purchase agreements that delivered to them precisely what they contracted for merely on the basis that they had not been informed before they closed that the project was progressing as anticipated without changes or delays. ${ }^{109}$

The decision in Woo makes the point that while (as stated by the OSC in Cornish) an overly technical approach to statutory language should not be relied upon to avoid disclosure obligations, an overly technical approach should not be taken to justify the avoidance of otherwise valid and binding contracts. The focus of the enquiry is on the materiality rather 
than the existence of a fact or a change, which, in the franchise context, requires a determination of its effect on the value or price of the franchise or on the decision to acquire it.

The case law repeatedly emphasizes that the standard to be applied to materiality determinations is objective. That standard operates whether the assessment is made under a reasonable investor test or a "market impact" type of analysis. The subjective concerns or intentions of a purchaser should not, in principle, be determinative of materiality assessments. Those challenging the adequacy of disclosure must offer objective evidence that satisfies the relevant test. Such an objective standard was addressed and applied by the Ontario Superior Court of Justice in Talon International Inc. v. Jung, ${ }^{110}$ a case decided under the Condominium Act, 1998. ${ }^{111}$ The Condominium Act, 1998 requires the delivery of a disclosure statement that must contain certain prescribed information to every person who purchases a unit or proposed unit. ${ }^{112}$ In the event that a material change occurs with respect to the information contained or required to be contained in the disclosure statement, a revised disclosure statement or notice must be delivered to each purchaser clearly identifying all changes that, in the reasonable belief of the declarant, may be material changes. ${ }^{113} \mathrm{~A}$ purchaser may rescind an agreement of purchase and sale before accepting a deed to the property "if a change or series of changes set out in a revised disclosure statement or a notice delivered to a purchaser constitutes a material change."114 "Material change" is defined in section 74(2) to mean:

[A] change or a series of changes that a reasonable purchaser, on an objective basis, would have regarded collectively as sufficiently important to the decision to purchase a unit or proposed unit in the corporation that it is likely that the purchaser would not have entered into an agreement of purchase and sale for the unit or the proposed unit or would have exercised the right to rescind such an agreement of purchase and sale under section 73 , if the disclosure statement had contained the change or series of changes. ${ }^{115}$

The purchasers in Jung entered into agreements of purchase and sale for commercial hotel units in a condominium development in 2005 after receiving the required disclosure statement. ${ }^{116}$ The vendor issued a revised disclosure statement in 2012 describing a number of changes. The purchasers claimed that the changes were material and purported to rescind their agreements. The vendor brought an application for a declaration that the agreements were valid and binding. The Superior Court of Justice agreed with the vendor that the changes were not material. In particular, the Court found that an alleged shift of a percentage of certain common element expenses onto the purchasers as disclosed in the revised statement was not material. Accepting the vendor's expert evidence on the issue, the Court held "that there has been no material change in the current disclosure, that there is no material change in the investment value to the unit holders, that there is no material change that objectively would have impacted a purchaser of a unit, and that there is no loss of a

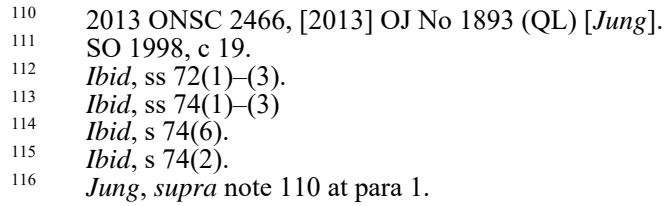


purchaser's investment value as a result of any of the foregoing." 117 The Court was satisfied that "a reasonable purchaser of these commercial units would not regard any of these changes or amendments as sufficiently important to his decision to purchase."

Similar conclusions were reached with respect to the other allegations of material change. The Court determined, although marginally, that the omission of the fact that the development would not be connected to an underground walkway system as specified in the original disclosure statement was not material. The purchasers offered no evidence that the value of their investments had been affected by the change, noting that the purchasers subjectively claimed that the change was material. The Court also rejected the argument that the removal of two hotel floors and the reduction of the overall size of the building from 70 to 60 floors represented a material change. ${ }^{119}$ Again, the court accepted the evidence of the vendor's expert to the effect that there was no change in the investment value of the units as a result of the changes disclosed in the revised statement and no depreciation in the income that the purchasers might have expected to receive from them. ${ }^{120}$

The purchasers appealed unsuccessfully. The Court of Appeal endorsed the reasons of the Court below, stating:

\footnotetext{
We also agree with the application judge that there were no material changes as that term [is] now defined in the Act. The term "material change" has a statutory definition in s. 74(2) which is purely objective. Obviously, the objective standard must take into account the context, but a purely subjective view, such as the difference to the purchaser, in this case, between a 70 story and a 60 story building does not meet this standard.
}

The essential context in this case in which to consider the issue of the alleged material changes is that these units were for investment purposes in a hotel. Thus, the primary issue, and the one addressed in the expert report, was whether any of the changes reasonably affected the value for investment purposes. ${ }^{121}$

The express inclusion of an objective standard in the Condominium Act, 1998 definition of material change should not diminish the relevance of that standard to the assessment of materiality under either the reasonable investor or material impact tests. What was essential with respect to materiality in this case was the nature of the assets that were purchased, namely, hotel investment units. As such, the impact of the changes on the value of those assets would be important in making a decision to purchase them notwithstanding the fact that the definition of material change makes no mention of an effect on value. What appears clear from these decisions is that materiality is not to be determined by the subjective views of those to whom a duty to disclose is owed.

Ibid at para 13 .

Ibid.

Ibid at para 17.

Ibid at para 14.

Talon International Inc v Jung, 2014 ONCA 137, [2014] OJ No 846 (QL) at paras 3-4. 


\section{Conclusion}

The cases reviewed above indicate that materiality is a question of mixed fact and law, determined on an objective basis. In the franchise context, franchisors and their counsel should apply a two-step analysis when considering whether to disclose a fact or a change. First, a determination must be made as to whether a fact that exists or a change that has occurred at the time disclosure is required to be made relates to the business, operations, capital, or control of the franchisor or any of its associates, the franchise system, or the franchise. If not, the change or fact need not be disclosed. If the answer to that question is yes, an assessment must be conducted to determine whether the fact or change would reasonably be expected to have a significant effect, or a significant adverse effect, on the value or price of the franchise or on the decision to acquire it. When looking at the decision to acquire the franchise piece, the question is not whether the disclosure of the fact or change would alter the decision, but the substantial likelihood that it would assume actual significance in the reasonable franchise purchaser's deliberations. That assessment is to be made in the context of the total mix of information that is disclosed.

Franchisors are in the best position to determine whether a fact or change would have a significant effect on the value or price of a franchise. In many, if not most cases, they will be able to make common sense judgments about what facts or changes will affect the value of their franchises. Where there is doubt, those tasked with preparing disclosure documents should look to objective evidence to substantiate their materiality determinations. Overly technical interpretations of the governing statutes' disclosure provisions should not be relied upon to justify non-disclosure.

Whether franchise disclosure issues will be judicially resolved on the basis of the reasonable investor test or on a market impact type of analysis remains to be seen. Being disjunctive with respect to the effect on value or price or the decision to acquire, the definitions of material fact and material change admit both. The characterization of the AWA as sui generis remedial legislation aimed squarely at the protection of franchisees indicates that the courts, at least in Ontario, will not be overly influenced by materiality determinations made in the context of other statutory disclosure regimes. Nonetheless, the question of materiality is increasingly being brought before the courts and recent pronouncements, some of which are discussed above, offer franchisors a broad framework within which to conduct their risk analyses on the question of whether to disclose or not disclose. 


\section{APPENDIX \\ ONTARIO SECURITIES COMMISSION \\ National Policy 51-201 Disclosure StaNdARds ${ }^{122}$}

\section{Part IV - Materiality}

\subsection{Materiality Standard}

(1) The definitions of "material fact" and "material change" under securities legislation are based on a market impact test. The definition of "privileged information" contained in the "tipping" provision of the securities legislation of Québec is based on a reasonable investor test. Despite these differences, the two materiality standards are likely to converge, for practical purposes, in most cases.

(2) The definition of a "material fact" includes a two part materiality test. A fact is material when it (i) significantly affects the market price or value of a security; or (ii) would reasonably be expected to have a significant effect on the market price or value of a security.

\subsection{Materiality Determinations}

(1) In making materiality judgements, it is necessary to take into account a number of factors that cannot be captured in a simple bright-line standard or test. These include the nature of the information itself, the volatility of the company's securities and prevailing market conditions. The materiality of a particular event or piece of information may vary between companies according to their size, the nature of their operations and many other factors. An event that is "significant" or "major" for a smaller company may not be material to a larger company. Companies should avoid taking an overly technical approach to determining materiality. Under volatile market conditions, apparently insignificant variances between earnings projections and actual results can have a significant impact on share price once released. For example, information regarding a company's ability to meet consensus earnings published by securities analysts should not be selectively disclosed before general public release.

(2) We encourage companies to monitor the market's reaction to information that is publicly disclosed. Ongoing monitoring and assessment of market reaction to different disclosure will be helpful when making materiality judgements in the future. As a guiding principle, if there is any doubt about whether particular information is material, we encourage companies to err on the side of materiality and release information publicly. 


\subsection{Examples of Potentially Material Information}

The following are examples of the types of events or information which may be material. This list is not exhaustive and is not a substitute for companies exercising their own judgment in making materiality determinations.

\section{Changes in Corporate Structure}

- changes in share ownership that may affect control of the company

- major reorganizations, amalgamations, or mergers

- take-over bids, issuer bids, or insider bids

\section{Changes in Capital Structure}

- the public or private sale of additional securities

- planned repurchases or redemptions of securities

- planned splits of common shares or offerings of warrants or rights to buy shares

- any share consolidation, share exchange, or stock dividend

- changes in a company's dividend payments or policies

- the possible initiation of a proxy fight

- material modifications to rights of security holders

\section{Changes in Financial Results}

- a significant increase or decrease in near-term earnings prospects

- unexpected changes in the financial results for any periods

- shifts in financial circumstances, such as cash flow reductions, major asset write-offs or write-downs

- changes in the value or composition of the company's assets

- any material change in the company's accounting policy

\section{Changes in Business and Operations}

- any development that affects the company's resources, technology, products or markets 
- a significant change in capital investment plans or corporate objectives

- major labour disputes or disputes with major contractors or suppliers

- significant new contracts, products, patents, or services or significant losses of contracts or business

- $\quad$ significant discoveries by resource companies

- changes to the board of directors or executive management, including the departure of the company's $\mathrm{CEO}, \mathrm{CFO}, \mathrm{COO}$ or president (or persons in equivalent positions)

- the commencement of, or developments in, material legal proceedings or regulatory matters

- waivers of corporate ethics and conduct rules for officers, directors, and other key employees

- any notice that reliance on a prior audit is no longer permissible

- de-listing of the company's securities or their movement from one quotation system or exchange to another

\section{Acquisitions and Dispositions}

- $\quad$ significant acquisitions or dispositions of assets, property or joint venture interests

- acquisitions of other companies, including a take-over bid for, or merger with, another company

\section{Changes in Credit Arrangements}

- the borrowing or lending of a significant amount of money

- $\quad$ any mortgaging or encumbering of the company's assets

- defaults under debt obligations, agreements to restructure debt, or planned enforcement procedures by a bank or any other creditors

- changes in rating agency decisions

- $\quad$ significant new credit arrangements

\subsection{External Political, Economic and Social Developments}

Companies are not generally required to interpret the impact of external political, economic and social developments on their affairs. However, if an external development will have or 
has had a direct effect on the business and affairs of a company that is both material and uncharacteristic of the effect generally experienced by other companies engaged in the same business or industry, the company is urged to explain, where practical, the particular impact on them. For example, a change in government policy that affects most companies in a particular industry does not require an announcement, but if it affects only one or a few companies in a material way, such companies should make an announcement.

\subsection{Exchange Policies}

(1) The Toronto Stock Exchange Inc. (the "TSX") and the TSX Venture Exchange Inc. ("TSX Venture") each have adopted timely disclosure policy statements which include many examples of the types of events or information which may be material. Companies should also refer to the guidance provided in these policies when trying to assess the materiality of a particular fact, change or piece of information.

(2) The TSX and TSX Venture policies require the timely disclosure of "material information". Material information includes both material facts and material changes relating to the business and affairs of a company. The timely disclosure obligations in the exchanges' policies exceed those found in securities legislation. It is not uncommon, or inappropriate, for exchanges to impose requirements on their listed companies which go beyond those imposed by securities legislation. We expect listed companies to comply with the requirements of the exchange they are listed on. Companies who do not comply with an exchange's requirements could find themselves subject to an administrative proceeding before a provincial securities regulator. 